\title{
Ease of Doing Business in Indonesia: A Long Road
}

\author{
Tomi Setianto ${ }^{1}$, Sam'un Jaja Raharja ${ }^{2}$ \\ ${ }^{1}$ Program Pascasarjana Administrasi Publik, Universitas Padjadjaran \\ ${ }^{2}$ Professor Departemen Administrasi Bisnis, FISIP Universitas Padjadjaran \\ e-mail: tomisetianto@gmail.com
}

\begin{abstract}
This paper discusses the ranking of Indonesia in various indicators of measuring Ease of doing business and attempts that Indonesia has taken to move up the Ease of doing business ranking. Indonesia's rank in the World Bank's Ease of Doing Business 2020 report stuck at 73 from last year ranking. Since the last two years, Indonesia did not have any significant policy in improving the business climate despite many measures already been taken by the government. The lack of a policy to improve the business climate and the increasing difficulty in starting a business has led to Indonesia's EODB ranking stagnation. Indonesia needs to reform more in order to be in top 50's EODB ranking by improving its business environment especially around starting a business, enforcing contracts, trading across border dan registering property.
\end{abstract}

Keywords: ease of doing business, EODB ranking, Indonesia

\section{PENDAHULUAN}

Pada laporan EODB Tahun 2020 yang dikeluarkan oleh World Bank, Indonesia meraih peringkat ke-73 dari 190 negara di dunia. Peringkat tersebut stagnan, tidak mengalami kenaikan dan penurunan seperti peringkat pada laporan tahun 2019 lalu. Masih sulitnya mendirikan usaha dan kurangnya kebijakan dalam peningkatan iklim berbisnis menjadi penyebab stagnansi peringkat Indonesia pada tahun ini (World Bank Group, 2019a). Padahal iklim lingkungan bisnis yang baik akan meningkatkan kinerja ekonomi suatu negara (Xu, 2011). Meskipun pertumbuhan ekonomi Indonesia tumbuh selama dalam kurun waktu 5 tahun, namun hal tersebut tidak selalu mencapai target APNB yang telah ditetapkan (BPS, 2019). Di tengah perang dagang pada pasar global yang menyebabkan ekonomi tak menentu, Neraca perdagangan Indonesia pada April 2019 mengalami defisit sebesar US\$ 2,5 miliar atau setara Rp. 36 triliun (Kusnandar, 2019). Defisit ini merupakan yang terdalam sepanjang sejarah Indonesia. Ada pun komponen ekspor Indonesia 60
\end{abstract}

persen berasal dari pertanian, mineral, dan logam. Masalah utama dengan mengandalkan komoditas mentah adalah harganya sangat tidak stabil. Puncak harga komoditas tersebut terjadi terakhir pada tahun 2011, ekonomi Indonesia tumbuh 6,5 persen. Ketika harga komoditas tersebut turun pada tahun 2014, pertumbuhan turun di bawah 5 persen. Sehingga perlu dilakukan reformasi struktural dalam komponen ekspor Indonesia (Muhamad, 2019).

Pertumbuhan Indonesia melambat karena penurunan harga komoditas global yang dimulai pada 2013, yang telah memotivasi negara untuk menghidupkan kembali pertumbuhan melalui promosi investasi. Indonesia mencapai periode stabilitas politik dan pertumbuhan PDB dengan rata-rata mencapai 5,7 persen per tahun antara 2004 dan 2013. Pemerintah Indonesia menargetkan ke tingkat pertumbuhan PDB sebesar 7 persen sebelum akhir masa jabatan pertama Presiden Joko Widodo pada 2019, di mana investasi sektor swasta akan menghasilkan sebagian besar dari pertumbuhan tersebut (Parlina I, 2014). 
Untuk melaksanakan inisiatif tersebut, Badan Koordinasi Penanaman Modal Indonesia (BKPM) telah menargetkan peningkatan FDI tahunan rata-rata sebesar 15 persen antara tahun 2015 dan 2019 (The Wall Street Journals, 2015). Sebagai akibatnya, Indonesia telah berhasil naik peringkat Doing Business dalam jangka waktu yang relatif singkat: dari posisi 129 ke 91 antara 2012 dan 2017.

KAJIAN LITELATUR

Sejak pertengahan tahun 2000-an, Bank Dunia telah menggunakan mekanisme pemeringkatan untuk mempengaruhi kebijakan pada negara-negara di dunia salah satunya yakni peringkat kemudahan berbisnis (ease of doing business). Dengan membuat laporan Doing Business dan Ease of Doing Business Index (EDB), Bank Dunia secara meyakinkan telah membentuk perilaku negara dalam menderegulasi urusan bisnis, terutama pada kondisi pasar yang sedang tumbuh dan pada negara-negara berkembang. Ease of Doing Business Index secara formal merupakan kegiatan pelaporan yang bersifat tidak memaksa dan tidak selalu akurat dalam mencerminkan peraturan suatu negara, keberadaannya telah memengaruhi pemerintah di seluruh dunia untuk mengubah kebijakan ekonomi dan peraturan terkait urusan bisnis. (Doshi, Kelley, \& Simmons, 2019). Dengan membuat tolak ukur yang berdasarkan peringkat, Bank Dunia memberikan tekanan sosial yang kompetitif pada berbagai negara untuk melakukan deregulasi atau perampingan aturan bisnis

Peringkat EODB oleh Bank Dunia dengannya merupakan alat yang mutakhir dalam mendorong perampingan aturan. Karena sebelumnya, Bank Dunia telah menggunakan cara-cara pinjaman tradisional dan bantuan teknis untuk memengaruhi strategi pembangunan pada negara-negara peminjam. Namun karena sejumlah alasan, cara-cara tersebut dipandang tidak efektif dalam menderegulasi aturan bisnis yang menghambat aktivitas pendirian usaha dan masuknya investasi. Dengan sistem pemeringkatan, negara-negara terdorong untuk menjadi lebih baik dari negara lainnya seperti halnya dalam sistem kompetisi olahraga. Hal ini merupakan esensi dari teori tekanan sosial yang melekat pada peringkat kemudahan bisnis. Yang mana hal ini melibatkan reputasi dan kepedulian terhadap status suatu negara, di mana di asumsikan jika peringkatnya suatu negara baik maka akan menimbulkan kebanggaan tersendiri bagi negara tersebut sehingga mereka terdorong untuk melakukan reformasi dalam merampingkan aturan bisnis yang menghambat pendirian usaha (Kelley \& Simmons, 2019).

\section{Gambar 1:}

Teori Pengaruh Sosial Pada Peringkat EODB

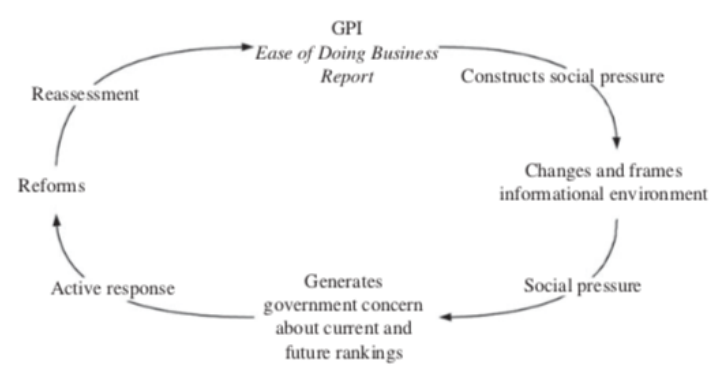

Laporan kemudahan berbisnis Bank Dunia telah menjadi alat penting dan tolok ukur untuk menentukan reformasi pada aturan bisnis dengan memberikan indikator kuantitatif pada peraturan yang memengaruhi kebelangsungan urusan bisnis di suatu negara. Kemudahan berbisnis (EODB) melihat perusahaan kecil, menengah dan menelusuri peraturan apa yang dapat meningkatkan aktivitas bisnis dan hal-hal apa saja membatasinya (Adepoju, 2017). EODB pertama kali diterbitkan pada tahun 2003, mencakup 5 indikator dan menilai 133 negara. Hingga saat ini, EODB telah mencakup 11 indikator dan 190 negara di dunia. Sebagian besar indikator mengacu pada skenario kasus pada kota-kota bisnis terbesar di setiap negara, kecuali untuk 11 negara yang memiliki populasi lebih dari 100 juta seperti Bangladesh, Brasil, Cina, India, Indonesia, Jepang, Indonesia, Nigeria, Pakistan, Federasi Rusia dan Amerika Serikat, dimana pada tahun 2013 Doing Business oleh Bank Dunia mengumpulkan data pada kota-kota bisnis kedua terbesar di negara tersebut. 
Proyek ini mendapat manfaat umpan balik dari pemerintah, akademisi, praktisi, dan pengamat di seluruh dunia. Sebagaimana dinyatakan di situs web Doing Business Bank Dunia, "tujuan utama dari laporan Doing Business yaitu untuk memberikan dasar objektif untuk memahami dan meningkatkan aturan yang mendukung lingkungan bisnis di seluruh dunia.". (World Bank Group, 2019a)

Sejak tahun 2006 ketika Bank Dunia mulai melacak nilai-nilai pada setiap negara, tercatat setidaknya 3.057 upaya reformasi yang telah dilakukan oleh negara-negara di penjuru dunia terkait dengan kemudahan berbisnis. Upaya bersama ini antara lain untuk meningkatkan peringkat suatu negara. Sejak saat itu pula negara-negara tersebut memulai berkolaborasi dengan pihak Bank Dunia selaku badan pemeringkat dalam menanggapi peringkat tersebut untuk memberikan saran kebijakan mengenai bagaimana praktik urusan kemudahan berbisnis seharusnya dilakukan dan dirampingkan (Doshi et al., 2019).

Laporan Doing Business Bank Dunia menggunakan beberapa kriteria dalam penilaian dan peringkat kemudahan dalam berbisnis:

1. Memulai bisnis (Starting a business): Prosedur, waktu, biaya, dan modal minimum yang dibayarkan untuk memulai sebuah perusahaan / perseroan terbatas.

2. Berurusan dengan izin konstruksi (Dealing with construction permits): Prosedur, waktu dan biaya untuk menyelesaikan semua formalitas untuk membangun Gudang, quality control, dan mekanisme keselamatan dalam sistem perizinan konstruksi.

3. Akses terhadap listrik (Getting electricity): Prosedur, waktu dan biaya untuk terhubung ke jaringan listrik, dan keandalan pasokan listrik dan transparansi tarif.

4. Mendaftarkan aset / properti (Registering property): Prosedur, waktu, dan biaya untuk mentransfer properti dan kualitas sistem administrasi pertanahan.
5. Mendapatkan kredit (Getting credit): Hukum jaminan aset dan sistem informasi kredit.

6. Melindungi investor minoritas (Protecting minority investors): Hak pemegang saham minoritas dalam transaksi dengan pihak terkait dan dalam tata kelola perusahaan.

7. Membayar pajak (Paying taxes): Pembayaran, waktu, total pajak dan tingkat kontribusi bagi perusahaan untuk mematuhi semua peraturan pajak serta proses pengarsipan.

8. Perdagangan lintas batas (Trading across borders): Waktu dan biaya untuk mengekspor produk dan impor suku cadang mobil

9. Menegakkan kontrak (Enforcing contracts): Waktu dan biaya untuk menyelesaikan sengketa komersial dan kualitas proses peradilan.

10. Menyelesaikan kebangkrutan (Resolving insolvency): Waktu, biaya, hasil, dan tingkat pemulihan untuk kebangkrutan komersial dan kekuatan kerangka hukum untuk kepailitan. (World Bank Group, 2018)

Kriteria lain yang dijadikan penilaian oleh Bank Dunia tetapi tidak digunakan pada pemeringkatan tersebut adalah mempekerjakan pegawai (employing worker) dan kewirausahaan (entrepreneurship). Kriteria tersebut yang disebutkan diatas, menentukan dan mengukur kemudahan yang digunakan bagi perusahaan dan investor untuk memulai suatu usaha pada suatu negara (Mendoza, Canare, \& Ang, 2015)

Dalam laporan Doing Business tahun 2020 yang merupakan laporan tahunan, Bank Dunia menyoroti beberapa temuan yang terjadi di berbagai dunia mengenai kemudahan berbisnis. Dalam laporan tersebut, Bank Dunia menangkap ada sekitar 294 reformasi regulasi yang dilaksanakan antara Mei 2018 dan Mei 2019. Di seluruh dunia, ada sekitar 115 kebijakan ekonomi yang membuat pendirian usaha menjadi lebih mudah. Namun juga, ada sekitar 26 kebijakan ekonomi yang malah tak ramah pada usaha 
pendirian usaha, di mana ada sekitar 31 perubahan peraturan yang menghambat efisiensi dan aturan yang mempersulit (World Bank Group, 2019a). Dalam laporan tersebut, secara rinci disebutkan bahwa perekonomi di Afrika dan Amerika Latin \& Karibia terus tertinggal dalam hal reformasi. Hanya ada dua negara di Afrika Sub-Sahara yang berada di peringkat 50 besar berdasarkan kemudahan berbisnis; dan tidak ada negara di Amerika Latin yang masuk dalam kelompok top 50. Sementara untuk negara-negara di Asia Timur dan Pasifik peringkatnya bervariasi, Singapore menjadi perwakilan Asia yang menduduki posisi atas yakni peringkat dua, dan top 20 dari Asia terdiri dari negara Hongkong, Malaysia dan Taiwan yang masing-masing menduduki peringkat ke 3. 12 dan 15. Sementara Indonesia, sebagai poros di negara ASEAN menduduki peringkat ke-73 pada laporan ease of doing business 2020.

\section{METODOLOGI}

Penelitian ini menggunakan data sekunder. Data dan informasi mengenai kemudahan bisnis (EODB) dan indikatornya diambil dari berbagai sumber antara lain World Bank Report on Doing Business 2020, EODB: Indonesia Profile 2020.

\section{HASIL DAN PEMBAHASAN}

Dalam laporan Doing Business 2020 oleh World Bank, Indonesia mendapati peringkat ke-73 dunia. Hal ini menunjukkan stagnansi peringkat seperti pada laporan tahun 2019 (World Bank Group, 2019a). Pada laporan tahun 2018, Indonesia meraih peringkat terbaik yang pernah di raih dalam kemudahan berbisnis, di mana posisinya menduduki peringkat ke-72. Lalu setelah itu, dalam kurun satu tahun, turun satu peringkat menjadi ke-73 disusul oleh negara El Savador. Peringkat Indonesia bila dibandingkan dengan negara-negara tetangga di ASEAN seperti Singapore, Malaysia dan Thailand masih sangat tertinggal.
Gambar 2:

Peringkat Indonesia Dalam EODB Ranking Periode 5 Tahun Terakhir

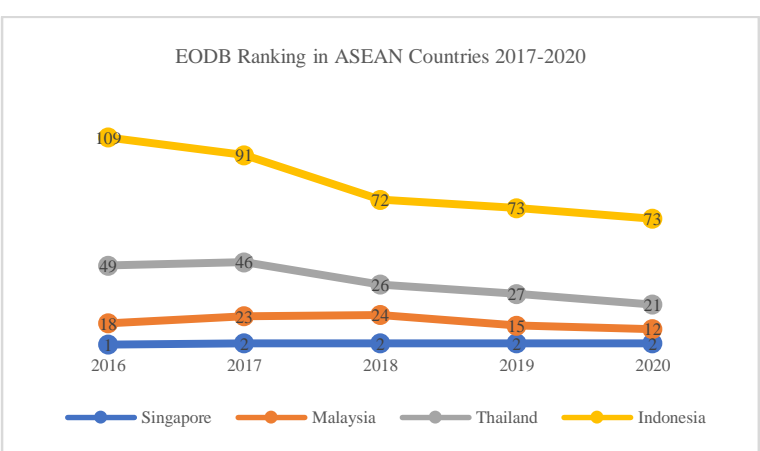

Sumber: (World Bank Group, 2019)

Meskipun tren peringkat Indonesia bersamaan dengan nilai indikator dan indikator unit selama kurun waktu lima tahun mengalami kenaikan semua indikator. Tercatat hanya dua indikator yang tidak mengalami perubahan, dan empat indikator mengalami peningkatan dalam laporan Doing Business 2020.

Tabel 1:

Tren Penurunan Peringkat Indonesia dalam EODB Indikators dalam 5 Tahun Terakhir

\begin{tabular}{|l|c|c|c|c|c|}
\hline \multicolumn{1}{|c|}{$\begin{array}{c}\text { EODB } \\
\text { Indicator }\end{array}$} & $\mathbf{2 0 1 6}$ & $\mathbf{2 0 1 7}$ & $\mathbf{2 0 1 8}$ & $\mathbf{2 0 1 9}$ & $\mathbf{2 0 2 0}$ \\
\cline { 2 - 6 } $\begin{array}{l}\text { Overall } \\
\text { Ranking }\end{array}$ & $\mathbf{1 0 9}$ & $\mathbf{9 1}$ & $\mathbf{7 2}$ & $\mathbf{7 3}$ & $\mathbf{7 3}$ \\
\hline $\begin{array}{l}\text { Doing Business } \\
\text { Score }\end{array}$ & $\mathbf{5 8 . 5 1}$ & $\mathbf{6 1 . 5 2}$ & $\mathbf{6 6 . 4 7}$ & $\mathbf{6 8 . 2}$ & $\mathbf{6 9 . 6}$ \\
\hline $\begin{array}{l}\text { *Starting a } \\
\text { business }\end{array}$ & 173 & 151 & 144 & 134 & 140 \\
\hline $\begin{array}{l}\text { Dealing with } \\
\text { construction } \\
\text { permits }\end{array}$ & 107 & 116 & 108 & 112 & 110 \\
\hline $\begin{array}{l}\text { Getting } \\
\text { electricity }\end{array}$ & 46 & 49 & 38 & 33 & 33 \\
\hline $\begin{array}{l}\text { *Registering } \\
\text { property }\end{array}$ & 131 & 118 & 106 & 100 & 106 \\
\hline Getting Credit & 70 & 62 & 55 & 44 & 48 \\
\hline $\begin{array}{l}\text { Protecting } \\
\text { minority } \\
\text { investors }\end{array}$ & 88 & 70 & 43 & 51 & 37 \\
\hline Paying taxes & 148 & 104 & 114 & 112 & 81 \\
\hline $\begin{array}{l}* \text { Trading across } \\
\text { borders }\end{array}$ & 105 & 108 & 112 & 116 & 116 \\
\hline $\begin{array}{l}\text { *Enforcing } \\
\text { contracts }\end{array}$ & 170 & 166 & 145 & 146 & 139 \\
\hline $\begin{array}{l}\text { Resolving } \\
\text { insolvency }\end{array}$ & 77 & 76 & 38 & 36 & 38 \\
\hline
\end{tabular}

Sumber: Doing Business in Indonesia (World Bank Group, 2020a)

Dapat dilihat dalam tabel bahwa peringkat Indonesia selama periode tersebut, tren nilai indikator unit mengalami 
peningkatan secara perlahan. Berikut akan dijelaskan mengenai peningkatan nilai dan stagnansi peringkat pada tahun 2020 berdasarkan indikator-indikator EODB; (1) starting a business; (2) dealing with construction permits; (3) getting electricity; (4) registering property; (5) getting credit; (6) protecting minority investors; (7) paying taxes; (8) trading across borders; (9) enforcing contracts; (10) resolving insolvency.

\section{Starting a business}

Indikator ini mengukur jumlah prosedur, waktu, biaya, dan persyaratan modal minimum yang dibayarkan untuk perusahaan kecil menengah dalam memulai dan menjalankan bisnis. Indonesia dalam kategori ini mengalami penurunan sebesar 6 poin dari posisi 134 menjadi 140 dengan rincian nilai sebesar $81 \%$. Ada pun dalam rincian indikator memulai bisnis, prosedur menjadi bobot yang tertinggal sebesar $41.2 \%$ dibanding waktu dan biaya masing-masing sebesar $90.5 \%$, dan biaya $97.2 \%$. Meskipun begitu, Indonesia menggunguli negara Philippines namun masih tertinggal oleh Malaysia dan Thailand. Ada pun usaha yang telah dilakukan oleh Indonesia dalam meningkatkan peringkatnya yaitu:

1. Tahun 2019, Indonesia (Jakarta) mempermudah memulai bisnis dengan memperkenalkan platform online untuk lisensi bisnis dan mengganti salinan cetak dengan sertifikat elektronik.

2. Tahun 2018, Indonesia membuat memulai bisnis lebih mudah dengan menggabungkan berbagai pendaftaran jaminan sosial dan dengan mengurangi biaya notaris di Jakarta dan Surabaya. Juga, pendaftaran yang berbeda digabungkan di toko serba ada di Surabaya.

3. Tahun 2017, Indonesia membuat memulai bisnis lebih murah dengan mengurangi biaya awal untuk perseroan terbatas.

4. Tahun 2016, Indonesia membuat memulai bisnis lebih mudah dengan membuat satu formulir untuk mengajukan sertifikat pendaftaran perusahaan dan lisensi perdagangan. Reformasi ini berlaku untuk Jakarta. Indonesia juga mempermudah memulai bisnis dengan menghapus persyaratan modal minimum untuk usaha kecil dan menengah dan dengan mendorong penggunaan sistem online untuk mencadangkan nama perusahaan.

5. Tahun 2015, Indonesia membuat memulai bisnis di Jakarta lebih mudah dengan mengurangi waktu yang dibutuhkan untuk mendaftar ke Departemen Tenaga Kerja.

6. Tahun 2014, Indonesia membuat memulai bisnis lebih mudah dengan memungkinkan Kementerian Hukum dan Hak Asasi Manusia untuk secara elektronik mengeluarkan surat persetujuan untuk akta pendirian.

7. Tahun 2011, Indonesia mempermudah awal bisnis dengan mengurangi biaya untuk pembersihan dan reservasi nama perusahaan serta waktu yang diperlukan untuk memesan nama dan menyetujui akta pendirian perusahaan.

8. Tahun 2009, Indonesia membuat memulai bisnis lebih mudah dengan memperkenalkan layanan online, menghilangkan lisensi tertentu, meningkatkan efisiensi dalam registrasi dan mengurangi beberapa biaya.

9. Tahun 2008, Indonesia membuat memulai bisnis lebih sulit dengan meningkatkan persyaratan modal minimum yang dibayarkan.

\section{Dealing with construction permits}

Indikator ini berkaitan dengan prosedur, waktu, dan biaya untuk membangun tempat atau gudang usaha, serta mengukur indeks kontrol kualitas bangunan, mengevaluasi kualitas peraturan bangunan, kekuatan kontrol kualitas dan mekanisme keselamatan, tanggung jawab dan jaminan asuransi, dan persyaratan sertifikasi profesional. Indonesia pada laporan Doing Business 2020, mengalami kenaikan peringkat dari tahun berikutnya yakni menjadi ke-110 dengan nlai skor yakni 66.8\%. Dan dalam kurun 10 tahun 
terakhir tidak memiliki kebijakan yang berkaitan dengan izin konstuksi. Hanya pada tahun 2007 Indonesia mempermudah penanganan izin konstruksi dengan menerapkan peraturan bangunan baru yang mencabut ketentuan sebelumnya tentang periode waktu untuk menyelesaikan izin bangunan- yang mengarah pada pengurangan waktu untuk mendapatkan izin bangunan. Hal ini menjadikan Indonesia tertinggal dari negara ASEAN seperti Phillippines, Thailand, Malaysia dan Singapura.

\section{Getting electricity}

Indikator ini mengukur prosedur, waktu dan biaya yang diperlukan untuk perusahaan dalam mendapatkan koneksi listrik permanen untuk tempat atau gudang yang baru dibangun. Serta mengukur keandalan pasokan, transparansi tarif, dan harga listrik. Indonesia mengalami stagnansi dalam peringkat ini yaitu ke-33 dari tahun sebelumnya dengan nilai skor yakni $87.3 \%$. Dari rincian laporan Doing Business 2020, disebutkan bahwa prosedur dalam mendapatkan akses listrik untuk Indonesia cukup sederhana dengan nilai skor 4 namun masih tetap tertinggal di banding dengan negara ASEAN seperti Phiilippines, Malaysia dan Thailand. Diikuti dengan waktu dalam proses mendapatkan listrik membutuhkan waktu yang cukup cepat dengan rata-rata 34 hari, sko ini cukup baik dibanding dengan Negara Asia Timur \& Pasific dan negara-negara OECD. Dalam sisi biaya, Indonesia mencetak nilai yang kurang baik yaitu skor 233 di mana biaya yang dibutuhkan cukup mahal dibandingkan dengan OECD yaitu sebesar 61. Secara keseluruhan nilai, Indonesia masih tertinggal oleh negara-negara ASEAN dimana Philippines, Thailad, dan Malasyia yang mana mendapatkan akses listrik lebih mudah dan cepat. Ada pun tercatat usaha yang telah dilakukan Indonesia dalam menaikan peringkatnya yaitu:

1. 2014, Indonesia membuat akses terhadap listrik lebih mudah dengan meningkatkan efisiensi proses penggunaan dan dengan menegakkan aturan "silence in consent" untuk persetujuan studi kelayakan pada koneksi baru.

2. Tahun 2013, Indonesia, pendistribusian penggunaan listrik menjadi lebih mudah dengan menyederhanakan prosedur, menawarkan peluang pelatihan kepada kontraktor swasta, menggunakan sistem informasi geografis (SIG) untuk memetakan jaringan distribusi listrik dan meningkatkan stok daya listrik.

\section{Registering property}

Indikator ini mengukur mengenai langkah-langkah, waktu dan biaya yang terlibat dalam mendaftarkan aset / properti, juga mengukur kualitas sistem administrasi pertanahan pada suatu negara. Indonesia mengalami penurunan sebesar 6 poin menjadi peringkat ke-106 dengan nilai indikator $60 \%$. Penurunan ini cukup mengantarkan peringkat Indonesia pada keseluruhan nilai EODB menurun. Ada pun usaha yang dilakukan yaitu:

1. Tahun 2018, Indonesia mempermudah pendaftaran properti dengan mengurangi waktu untuk menyelesaikan sengketa tanah di Pengadilan Tingkat Pertama dan meningkatkan transparansi daftar tanah.

2. Tahun 2017, Indonesia mempermudah pendaftaran properti dengan mengurangi pajak transfer.

3. Tahun 2016, Indonesia mempermudah pendaftaran properti dengan mendigitalkan catatan kadaster dan membuat sistem informasi geografis.

4. Tahun 2009, Indonesia mempermudah pendaftaran properti dengan memperkenalkan batas waktu untuk prosedur di pendaftaran tanah.

\section{Getting credit}

Indikator ini berkaitan dengan mengukur hak hukum peminjam dan pemberi pinjaman yang terkait dengan jaminan transaksi dan pelaporan informasi kredit. Indonesia mengalami penurunan sebesar 4 poin dari peringkat 44 menjadi ke-48 nilai indikator sebesar $70 \%$. Tren peningkatan 
selama kurun waktu lima tahun pun selalu mengalami peningkatan namun pada laporan tahun 2020 tidak. Hal ini tentu karena berbagai upaya yang telah dilakukan pemerintah Indonesia dalam memudahkan publik dalam mendapatkan kredit atau pinjaman untuk mendirikan usaha. Ada pun histori usaha pemerintah Indonesia dalam upayanya meningkatan peringkat pada kategori ini terhitung sejak tahun 2012 sebagai berikut:

1. Tahun 2018, Indonesia meningkatkan akses ke informasi kredit dengan mendistribusikan data dari pengecer dan perusahaan utilitas.

2. Tahun 2017, Indonesia meningkatkan akses ke informasi kredit dengan meluncurkan biro kredit baru.

3. Tahun 2016, Indonesia memperkuat akses ke kredit dengan membuat pendaftaran agunan modern.

4. Tahun 2015, Indonesia meningkatkan akses ke kredit dengan memungkinkan pencarian pendaftaran agunan dengan nama debitur.

5. Tahun 2013, Indonesia meningkatkan sistem informasi kreditnya melalui peraturan baru yang menetapkan kerangka hukum untuk mendirikan biro kredit.

6. Tahun 2008, Indonesia meningkatkan akses ke informasi kredit dengan menjamin hak peminjam untuk memeriksa data mereka sendiri dalam daftar kredit publik.

7. Tahun 2007, Indonesia menghilangkan ambang minimum untuk pinjaman yang termasuk dalam database-nya, meningkatkan akses ke informasi kredit.

\section{Protecting minority investors}

Indikator ini mengukur kekuatan perlindungan pemegang saham minoritas terhadap penyalahgunaan aset perusahaan oleh direksi serta hak-hak pemegang saham, perlindungan tata kelola, dan transparansi perusahaan yang mengurangi risiko penyalahgunaan. Pada kategori ini Indonesia mengalami kenaikan yang cukup besar dari peringkat 51 ke 37 pada laporan 2020. Hal ini menujukan peringkatan yang cukup signifikan, namun tetap tertinggal oleh negara seperti Malaysia dan Thailand, namun unggul dari Philippines. Dalam tren peringkat selama kurun waktu lima tahun juga menunjukan bahwa peringkat Indonesia fluktuatif, artinya pemerintah Indonesia belum memiliki komitmen yang kuat terhadap perlindungan pada investor minoritas dalam aktivitas bisnis seperti dalam pemegang saham dan kepemilikan perusahaan. Ada pun usaha yang dilakukan pemerintah Indonesia yaitu:

1. Tahun 2017, Indonesia memperkuat perlindungan investor minoritas dengan meningkatkan hak-hak pemegang saham dan perannya dalam keputusankeputusan perusahaan besar dan membutuhkan transparansi perusahaan yang lebih besar.

2. Tahun 2009, Indonesia memperkuat perlindungan investor dengan meningkatkan persyaratan pengungkapan untuk transaksi dengan pihak terkait.

3. Tahun 2007, Indonesia memperkuat perlindungan investor dengan memperluas persyaratan pengungkapan yang sudah luas bagi perusahaan yang terdaftar di bursa saham.

\section{Paying taxes}

Indikator ini mengukur pajak dan kontribusi wajib yang harus dibayar atau ditahan pada perusahaan skala menengah di tahun tertentu, serta beban administrasi untuk membayar pajak dan kontribusi serta kepatuhan prosedur pajak. Indonesia pada laporan 2020 mengalami peningkatan dari peringkat 112 menjadi ke-81 dan dengan nilai indikator sebesar $75.8 \%$. Komponen dari indikator unit ini ditemukan bahwa waktu dan total pajak dan kontribusi serta indeks kepatuhan masih memiliki nilai rendah dibanding dengan negara seperti Thailand dan Malayia. Namun begitu, tren pembayaran pajak selama kurun waktu lima tahun pun selalu mengalami peningkatan yang cukup signifikan. Artinya pembayaran 
pajak pada aktivitas usaha semakin membaik dilakukan oleh pemerintah Indonesia meskipun masih butuh peningkatan dalam kategori ini. Ada pun histori upaya yang telah dilakukan pemerintah Indonesia dalam meningkatkan peningkatan dalam pajak yakni:

1. Tahun 2019, Indonesia mempermudah pembayaran pajak dengan memperkenalkan sistem pengarsipan dan pembayaran online untuk pajak-pajak utama.

2. Tahun 2017, Indonesia dibuat membayar pajak lebih mudah dengan mempromosikan pengajuan online pajak dan dengan menurunkan tingkat pajak keuntungan modal. Indonesia juga menambah plafon yang digunakan dalam perhitungan kontribusi perawatan kesehatan.

3. Tahun 2016, Indonesia mempermudah pembayaran pajak dengan memperkenalkan sistem online untuk mengajukan dan membayar kontribusi kesehatan. Indonesia juga membuat membayar pajak lebih mahal dengan memungut iuran pensiun baru dengan tingkat pembayaran $2 \%$ oleh pengusaha.

4. Tahun 2015, Indonesia membuat pembayaran pajak menjadi lebih mudah dan lebih murah untuk perusahaan dengan memperkenalkan sistem online untuk membayar kontribusi jaminan sosial dan dengan mengurangi tingkat yang dibayarkan oleh pengusaha dan batas tertinggi untuk kontribusi.

5. Tahun 2014, Indonesia membuat membayar pajak lebih murah bagi perusahaan dengan mengurangi tingkat kontribusi asuransi kesehatan pengusaha.

6. Tahun 2010, Indonesia mengurangi tarif pajak penghasilan badannya.

7. Tahun 2009, Indonesia membuat membayar pajak lebih murah bagi perusahaan dengan mengurangi tarif pajak penghasilan badan tertinggi.

8. Tahun 2007, Indonesia mempermudah pembayaran pajak bagi perusahaan dengan menyederhanakan persyaratan pengarsipan dan mendorong penggunaan sistem elektronik.

\section{Trading across borders}

Indikator ini mengukur waktu dan biaya yang terkait dengan proses logistik ekspor dan impor barang. Indikator ini mengukur waktu dan biaya (tidak termasuk tarif) yang terkait dengan tiga rangkaian prosedur yaitu kepatuhan dokumen, perbatasan, dan transportasi domestic dalam keseluruhan proses ekspor atau impor pengiriman barang. Indonesia dalam laporan tahun 2020 pada indikator ini tidak mengalami penurunan dan kenaikan peringkat, ada pada posisi ke-116 serta nilai indikator sebesar $67.5 \%$. Hal ini menunjukkan peringkat yang kurang baik dibanding dengan negara-negara seperti Malaysia dan Thailand. Namun dalam rincian indikator unit ini dibutuhkan biaya dan waktu yang cukup tinggi dalam hal border compliance dan documentary compliance dalam aktivitas ekspor dan impor. Usaha yang telah dilakukan oleh Indonesia antara lain:

1. Tahun 2019, Indonesia membuat perdagangan lintas batas lebih mudah dengan meningkatkan pemrosesan online. Reformasi ini berlaku untuk Jakarta dan Surabaya.

2. Tahun 2017, membuat impor lebih cepat dengan memperkenalkan sistem penagihan tunggal elektronik.

3. Tahun 2016, membuat ekspor dan impor menjadi lebih mudah dengan meningkatkan layanan kepabeanan dan mendokumentasikan fungsi pengiriman melalui National Single Window Indonesia.

4. Tahun 2014, perdagangan lintas batas menjadi lebih sulit karena infrastruktur yang tidak memadai di Pelabuhan Tanjung Priok Jakarta. Perubahan ini berlaku untuk Jakarta dan Surabaya.

5. Tahun 2010, Indonesia mengurangi waktu untuk mengekspor dengan meluncurkan layanan satu jendela. 


\section{Enforcing contracts}

Indikator penegakan kontrak mengukur waktu dan biaya untuk menyelesaikan sengketa usaha melalui pengadilan tingkat pertama pada level lokal, dan kualitas proses peradilan, mengevaluasi apakah setiap negara telah mengadopsi serangkaian praktik yang baik yang mempromosikan kualitas dan efisiensi dalam sistem pengadilan. Dalam laporan Doing Business 2020, Indonesia dalam hal ini menujukkan kenaikan tahun sebelumnya dengan nilai peringkat ke-139 dari 146 dengan nilai capaian nilai sebesar 49.1\%. Dalam sampel Jakarta, dibutuhkan sekitar 390 hari untuk menyelesaikan kasus persengketaan usaha yang mana dalam hal ini termasuk dalam kategori cepat bila dibandingkan dengan negara-negara di Asia Timur \& Pasifik dan OECD yang masingmasing memiliki waktu sekitar 581.1 dan 589 hari. Namun dalam hal biaya persengketaan / klaim, dibutuhkan biaya yang cukup tinggi dengan persentase $16.9 \%$ yang mana tertinggi kedua setelah Philippines dibanding negara-negara ASEAN seperti Malaysia dan Thailand. Diikuti dengan kualitas peradilan yang rendah dalam hal persengketaan dengan nilai 9.0 dari 18. Ada pun usaha dilakukan pemerintah dalam aspek ini yaitu:

1. Tahun 2019, Indonesia mempermudah pelaksanaan kontrak dengan memperkenalkan sistem manajemen elektronik untuk para hakim. Reformasi ini berlaku untuk Jakarta dan Surabaya.

2. Tahun 2018, Penyederhanaan waktu untuk Filing and service dan Trial and judgment di DKI Jakarta dan Surabaya.

3. Tahun 2016, Indonesia membuat kontrak penegakan lebih mudah dengan memperkenalkan prosedur khusus untuk klaim kecil yang memungkinkan perwakilan diri. Reformasi ini berlaku untuk Jakarta dan Surabaya.

\section{Resolving insolvency}

Indikator ini berkaitan dengan waktu, biaya, hasil, dan kecepatan pemulihan untuk kepailitan usaha dan kekuatan kerangka hukum untuk kepailitan. Nilai Indonesia dalam kategori penyelesaian kepailitan menurun dua poin dari 36 ke 38 dan nilai capaian indikator sebesar $68.1 \%$. Namun begitu, Indonesia tetap unggul dibanding negara-negara ASEAN seperti Malaysia dan Philipphines yang masing-masing memiliki nilai 67.0 dan 55.1 tetapi kalah saing oleh negara Thailand dengan nilai 76.8 (World Bank Group, 2020b). Ada pun waktu yang dibutuhkan untuk menyelesaikan kepailitan ada pada nilai 1.1 di mana dibandingkan dengan rata-rata nilai negara-negara di Asia Timur dan Pasifik masih unggul dengan nilai 2.6, sedangkan dalam biaya Indonesia tertinggal dimana biaya dibutuhkan untuk menyelesaikan kepailitan dianggap masih mahal dibanding dengan rata-rata pada negara tersebut.

\section{SIMPULAN}

Usaha yang telah dilakukan Indonesia dalam mereformasi aturan dan kebijakan untuk memudahkan urusan bisnis hanya mampu menghantarkannya pada peringkat terbaiknya yakni ke-72 dunia pada tahun 2018. Namun tercatat sejak tahun tersebut, khususnya dalam kurun waktu lima tahun terakhir dalam laporan Doing Business 2020, Indonesia masih belum memiliki kebijakan yang secara signifikan meningkatkan iklim bisnisnya dan meningkatan pemeringkatan pada EODB. Karenanya, stagnansi peringkat terjadi pada tahun ini dan akan mengalami penurunan bila pemerintah Indonesia tidak cepat bertindak dalam merampingkan aktivitas urusan bisnis. Sehingga dibutuhkan lebih banyak reformasi dan transparansi bagi Indonesia untuk masuk dalam peringkat 50 besar. Perbaikan harus dilakukan pada hampir semua bidang indikator dalam EODB khususnya tiga indikator yang menempati skor terburuk yaitu starting busness, enforcing contracts, trading across border dan registering property.

\section{DAFTAR PUSTAKA}

Adepoju, U. K. (2017). Ease of Doing Business and Economic Growth. Working Paper, Department of Economics of the University of Ottawa, 


\section{Ease of Doing Business in Indonesia: A Long Road}

(December).

BPS. (2019). Nota Keuangan APBN 2014 2018.

Doshi, R., Kelley, J. G., \& Simmons, B. A. (2019). The Power of Ranking: The Ease of Doing Business Indicator and Global Regulatory Behavior. In International Organization (Vol. 73). https://doi.org/10.1017/s00208183190 00158

Kelley, J. G., \& Simmons, B. A. (2019). Introduction: The Power of Global Performance Indicators. International Organization, 73(03), 491-510. https://doi.org/10.1017/s00208183190 00146

Kusnandar, V. B. (2019). April 2019, Defisit Neraca Perdagangan Indonesia Terdalam Sepanjang Sejarah. Katadata. Retrieved from https://databoks.katadata.co.id/datapub lish/2019/05/16/april-2019-defisitneraca-perdagangan-indonesiaterdalam-sepanjang-sejarah

Mendoza, R., Canare, T., \& Ang, A. (2015). Doing business: A review of literature and its role in APEC 2015. Research Paper Series, (October).

Muhamad, D. (2019). Delivering structural transformation to Indonesia. Thejakartapost. Retrieved from https://www.thejakartapost.com/news/ 2019/10/28/delivering-structural- transformation-indonesia.html

Parlina I. (2014). Jokowi aims for 7 percent annual growth. Thejakartapost. Retrieved from www.thejakartapost.com/news/2014/1 2/24/jokowi-aims-7-percent-annualgrowth.html

The Wall Street Journals. (2015). Indonesia's investment aims - the numbers.

World Bank Group. (2018). Doing Business 2019: Training for Reform. World Bank. https://doi.org/10.1596/978-14648-1326-9

World Bank Group. (2019a). Doing Business $2020 . \quad$ Retrieved from https://www.doingbusiness.org/en/rep orts/global-reports/doing-business2020

World Bank Group. (2019b). Ease of Doing Business Rankings: Latin America \& Caribbean. Retrieved from https://www.doingbusiness.org/en/ran kings?region=latin-america-andcaribbean

World Bank Group. (2020a). Doing Business 2020: Economy Profile of Indonesia.

$\mathrm{Xu}, \mathrm{L} . \mathrm{C}$. (2011). The effects of business environments on development: Surveying new firm-level evidence. World Bank Research Observer, 26(2), 310-340.

https://doi.org/10.1093/wbro/lkq012 